\title{
E - Governance Implementation and Public Service Delivery in Nigeria: The Technology Acceptance Model (TAM) Application
}

\author{
Olalekan Ajibade, Jide Ibietan, PhD \& Oludare Ayelabola \\ Department of Political Science and International Relations, \\ Covenant University, Ota, Ogun State, Nigeria \\ E-mail: ajibade_olalekan@yahoo.com; olajide.ibietan@covenantuniversity.edu.ng
}

Received: Jun. 30, 2017 Accepted: Nov. 4, $2017 \quad$ Online published: Nov. 20, 2017

doi:10.5296/jpag.v7i4.11475 URL: https://doi.org/10.5296/jpag.v7i4.11475

\begin{abstract}
The aim of this paper is to explain the relationship between e-governance implementation and public service delivery in Nigeria using the Technology Acceptance Model. The paper is qualitative in nature and relies on secondary sources for data collection and the discussion that followed. The paper found that there are certain obstacles that hinder the adoption and effective implementation of e-governance that would have engendered qualitative service delivery in public sector organisations in Nigeria. It is in line with the foregoing, that this paper concludes that tackling the obstacles to e-governance adoption, implementation is key to the achievement of better public service delivery. The paper therefore recommends the sensitization of public servants on the importance and benefits of adopting and implementing e-governance in their administrative and organizational processes that will ultimately lead to improved service delivery in Nigeria among others.
\end{abstract}

Keywords: adoption, e-governance, Nigeria, public, service delivery

\section{Introduction}

In recent times, the level of advancement of Information and Communication Technology (ICT) in Nigeria has reached a crescendo. This is also because the usage of technology has permeated almost all endeavors of life, by providing ways of ensuring efficient, easy processing and delivery of services. This makes the application of technology to service delivery imperative (Banks, Oxman, Rodger \& Irish, 2002). E-governance is no doubt a tool for managing the activities of the public service at the global level. Its application has aided the swift delivery of services in developed nations of the world. In most countries of 
the world, revitalizing the public service so as to make it effective, efficient and people-centred through the adoption of new and emerging technologies for speedy delivery of services to the populace has become quite imperative. In this context, information and communication technology have been recognized as an effective tool that could assist government reinvent itself faster, run cheaply, better and produce newer outcomes (Heeks, 1999 cited in Omeire \& Omeire, 2014). E-governance in its simple term refers to the application of ICT to improve the delivery of services in the public service to attain transparency, accountability, timeliness, and efficiency (Azeez, Abidoye, Adesina, Agbele \& Venter, 2012). The implementation of e-governance cannot become a reality without the adoption of modern day technologies (ITU, 2006). Although from the traditional practice of administration, ICT have been in use in businesses and other fields, governments across the world are beginning to embrace and deploy information communication technology to the public service due to the fact that they have realized that the application of ICT is a useful tool that can leverage public sector organisations to change from their routine command and control organisations that are inwardly focused on administration to knowledge-based, networked, learning organisations that are externally focused on service delivery (OECD, 2005).

Nowadays, terms like e-government and e-governance are used interchangeably but have different meanings. For instance, e-government as a term is used to describe the use of information technology by the government in exchange for services and information, while the term e-governance refers to a process in which technology is used to share and provide information, services and transact businesses between the government, among other arms and agencies of government with the citizens. In an attempt to improve service delivery by the Nigerian government, the public sector has undergone massive process of reforms in the last two decades (Bureau of Public Service Reforms, 2007). Service delivery is the object and subject of all reforms.

The reforms in Nigeria include privatization and commercialization of public organizations, monetization policy, downsizing in the public sector, service compact (SERVCOM) to mention but a few. In addition to the aforementioned reforms, the Nigerian government has also incorporated Electronic-Governance (e-governance) in their activities in order to improve efficiency, transparency and accountability in the public sector. The aim of this paper is to explain the relationship between e-governance implementation and public service delivery in Nigeria using the Technology Acceptance Model. After the introduction, the paper reviews relevant literature on e-governance and service delivery which presents the concept of e-governance, objectives of e-governance and the concept of service delivery and thereafter, it takes a look at the challenges to the adoption and effective implementation of e-governance in Nigeria before discussing the Technology Acceptance Model (TAM) which is the theoretical framework for this paper. The last section makes recommendations and concludes this study. 


\section{Literature Review}

The concepts of e-governance and public service delivery are explained in this section.

\subsection{Concept of E-Governance and Public Service Delivery}

The origin of e-governance is from the word governance. The term governance is referred to as the use of economic, political and administrative power when managing a nation's affair, which includes citizen's interest articulation and the exercise of legal rights and obligations (Ojo, 2014). This definition by implication, opines that governance is good when citizen's rights are put into consideration and their inputs are recognised in the policy formulation process. There are different opinions on e-governance from various scholars. To Estevez \& Janowski (2013), E-governance is the application of technology by government organisations to transform its activities and its interactions with the citizen so as to create an impactful society. Bannister and Walsh (2002) view e-governance as a concept that contains the application of information and communication technology by a number of government agencies and civil society in stimulating the frequent participation of citizens in the governing and administrative process of political institutions. Sunday (2014) similarly opines that e-governance is the use of ICT by departments of government to promote accountability, awareness creation and further guarantee openness in the administration of government. In other words, administrative and managerial processes of an organization is the major concern of e-governance. Palvia and Sharma (2007) substantiate this view by asserting that the basic focus of e-governance is the internal utilization of information and internet technologies in the management of certain resources such as human, material, capital and machines, which are arranged to aid managerial activities in an organization.

Nkwe (2012) in his argument, asserts that e-governance is a shift from the traditional model of public administration. The shift is in terms of the delivery of government services to the citizens through the use of ICT. In agreement with the forgoing, Ayo (2014) described e-governance as the governance of a nation through the use of Information Communication Technology. By this definition, the adoption of technology enhances the effectiveness, efficiency, accountability and transparency in the exchange of information. From the above, e-governance is adopting the use of technology in an effective, efficient manner in the exercise of economic, political, administrative and social management of public affairs by involving the citizens in public policy making. The adoption of e-governance involves citizens in public policy making which facilitates the easy implementation of policies for enhanced delivery of public services (Ayo, 2014). Adopting e-governance facilitates significant reduction in government expenses, while increasing the earned interest and ability to reduce government contracts (Fatile, 2012). When discussing e-governance, it is more than just talking about a government website on the internet. E-Governance has some strategic objectives. The strategic objectives of e-governance are to streamline and upkeep governance amongst government, citizens, businesses and parties. Using information and communication technology would create a connection among these parties and aid the activities and procedures involved. Electronic governance is also known as support system which motivates good governance. Therefore, there is similarity between the objectives of 
e-governance and that of good governance. Wimmer and Traunmiller (2001) highlight the following as the main objectives of e-governance;

i. Reduction and overcoming hurdles to coordination and cooperation within public administration.

ii. Administrative processes and function restructuring

iii. Monitoring government's performance.

Other scholars see e-governance as a type of public service whose operations are in a one-stop, non-stop routine (Lawson, 2008). Heeks (1996) underscores e-governance as an integrated governance that helps to facilitate both the processing of information by people and the use of communication technologies to accomplish the objectives of governance.

The above explains that e-governance is an approach for enhancing the quality of services delivered to the citizens. E-government involves the use of ICTs to transform government processes and provides services, information and knowledge to the public. It builds better relationships between government and the public by facilitating interaction with citizens in a smoother, easier, and more efficient manner. The above definitions and perspectives on e-governance highlights the use of information technology to improve service delivery to the citizens and ensures faster communication between governments and the citizens. The following can be deduced as the features of e-governance:

- E-governance is a combination of processes and structures.

- Interaction exists between the government and the citizens.

- The application of software, hardware, internet and various ICT devices are adopted to govern.

- It is a public sector reform targeted at digitalizing processes of government and delivery of public services at all levels.

- It is a mechanism aimed at improving the conduct of government businesses.

\section{The Concept of Public Service Delivery}

Carlson, Davis and Leach (2005) in their work conceptualized service delivery as the relationship that exist between policy makers, service providers and the populace. To them, it consist of services and its supporting systems which are generally referred to as state responsibility. These services include infrastructure, social services and services that enhance personal security. Public service delivery can be regarded as providing citizens with services of public interest. Examples of these services of public interest include: security, education, energy, water, public transport and healthcare. Service delivery according to Yayale, (2004), presupposes that in public service, there is a contractual relationship between the public and a government agency in which the latter is legally bound to render service to the former in terms of quality. To Fox and Meyer (1996), public service delivery is the provision of public goods which are tangible, and services which are intangible and the private sector cannot produce. Similarly, Riekert (2001) views service delivery as the provision of a product or 
service by a government body to the citizens. Due to the increase in customers' expectations and technological revolution, public sector organizations have come under increasing pressure to deliver quality services and improve efficiency like the private sector (Robinson, 2003). Customer needs and expectations, according to (Osawe, 2015) are changing when it comes to governmental services and their quality requirements. However, service quality is a measure of how well the service level delivered matches customers' expectations. Thus, government are saddled with the responsibilities of providing goods and services that meet the citizen's expectations.

\subsection{History of E-governance Implementation in Nigeria's Civil Service}

The Nigerian government over the years have taken drastic measures at putting the nation on track in the area of information and communication technology advancement and its utilization in governance. In the year 2001, the government of Nigeria launched her national information technology policy and thereafter, the implementation of this policy began with the establishment of National Information Technology Development Agency (NITDA). However, the implementation of e-governance in Nigeria differs from one level and agency to the other. This implementation created an attempt to provide a unified national framework of Information and Communication Technology adoption in governance. The federal government of Nigeria made an announcement on the importance of her ICT policy for the nation in 2001 (Olatokun \& Adebayo, 2012). E-governance created an awareness that no country or its government can perform its duties effectively in this era, without the adoption of technology. That is, applying internet services, in the process of service delivery. The Nigerian federal government saw the necessity for the nation to have a national policy on Information and Communication Technology as a result of the importance of ICT in governance. Thus, the enabling policy on ICT gave rise to the National Information Technology Development Act by the National Assembly in 2007 with the establishment of this agency (Olatokun \& Adebayo, 2012). With this enabling Act, many of the agencies of government started the implementation of information and communication technology in their operations. Moreso, that the federal government created the new Ministry of Communication Technology. Part of the responsibilities conferred on this ministry is to coordinate ICT development and make progress as regard's the country's target on e-governance (Omerie \& Omeire, 2014). Recently, there are various strategies evolved to accelerate the development of technology in Nigeria (Fatile, 2012). The E-Nigeria initiative was an attempt towards the connection of communities, relevant agencies, government organisations including educational institutions at all levels with information and communication technology pursued currently by the government. The ICT implementation project started from the National Rural Telephony programme, and includes the Public Service Network, ICT facilities loan scheme at state and local government levels, internet exchange point initiative and the wire Nigeria idea. These ICT implementation strategies are targeted at enabling accelerated growth of the nation (Ekeh, 2007). The mechanisms and skills required by a country to realize these initiatives is to make computers and other ICT enhancing equipment flexible and cheap for citizens to acquire. Presently, there is an easy access of allocations to both state and local governments on the Ministry of Finance official 
website. The public display of these allocations would enhance accountability and transparency across the levels of government (Muhammad, Abubakar \& Bashir, 2010).

\section{Method of the Study}

This paper adopts a qualitative research approach. To achieve the objective of this study, data were sourced from secondary materials including relevant books, journals and internet resources to ascertain the current level of e-governance implementation in the delivery of public services in Nigeria using the Technology Acceptance Model (TAM) as framework of analysis.

\section{Theoretical Perspective}

This study adopts the Technology Acceptance Model (TAM) as theoretical framework for this study. The Technology Acceptance Model (TAM) was proposed by Fred Davies in 1989. The model was an expansion on Arzen and Fishben's (1967) Theory of Reasoned Action. Technology Acceptance Model (TAM) emphasises the acceptability of an information system. The objective of this model is to predict the acceptability of a tool for use and to identify the modifications which must be brought to the system in order to make it acceptable to users. This model suggests that the acceptability of an information system is determined by two main factors: perceived usefulness and perceived ease of use (Venkatesh, Morris, Davis and Davis, 2003). TAM posits that perceived usefulness and perceived ease of use determine an individual's intention which serves as a mediator of actual system use. Perceived usefulness is also seen as being directly impacted by ease of use (Venkatesh, Morris, Davis and Davis, 2003).

Technology Acceptance Model (TAM) is quite different from the original version of Reasoned Action. The differences are in two categories: first, is that the model introduced two new constructs; perceived usefulness and perceived ease of use. The first construct (perceived usefulness) believes that the usage of an application would increase performance while the other construct (perceived ease of use) believes that the use of application would make work stress-free (Shih, Shing \& Chien, 2011). Ducey (2013) in his work, gave a clearer explanation that the two constructs of Technology Acceptance Model (TAM) are of high importance as they determine technology acceptance and users' behaviour. One of the goals of Technology Acceptance Model is the provision for explanation that determines the acceptance of technology generally. This goal is capable of explaining behaviour of users across a wide range of population. Thus, the main purpose of the Technology Acceptance Model (TAM) is the provision of foundation to trace the effect of external factors on attitudes, internal beliefs and intentions in the organisation.

The theory is applicable to the practice of e-governance in the Nigerian public sector. Technology Acceptance Model is relevant to the Nigerian civil service as it explains the role played by self-efficacy, perceived cost, technological infrastructure, power supply, and internet facilities to support the adoption of e-governance. The application of Technology Acceptance Model (TAM) is enhanced due to its simplicity together with the predictive authority which makes its application easy to different situations (Venkatesh, 2000). 
Technology Acceptance Model is useful in explaining the acceptance, application, relevance and effectiveness of modern technologies in information sharing among citizens, literacy level and galvanises public service delivery. The application of TAM to a study like this underscores user's technological behaviour and actual utilization. From the unit of analysis and with the assumptions of the Technology Acceptance Model (TAM), the model is relevant and applicable to the discussion of e-governance implementation and public service delivery in Nigeria.

\section{Hurdles to the Implementation of E-Governance in Nigeria}

The hurdles to e-governance implementation in Nigeria are similar to those of other developing nations. Scholars like Abasilim \& Edet, (2015); Abasilim, Gberevbie \& Ifaloye, (2017) agreed that one of the hurdles to the implementation of e-governance in Nigeria is poor telecommunications and internet facilities. Fatile (2012) captures this issue by emphasising that the enabling technological frameworks for the adoption and implementation of e-governance are substandard and insufficient. Telecommunication facilities are in this category. Abdulrazaq (2015) highlighted the obstacles to the implementation of e-governance in Nigeria to include the following:

Infrastructural Deficit: ICT facilities in Nigeria are urban based. Most of the telecommunication base stations are located in the urban areas, with little or no access to the rural areas. Although the tele-density rate of the nation is high at almost 90 percent now. The rate and level of internet usage in the country is not encouraging and this adds to the challenges facing the implementation of e-governance in Nigeria.

Digital Divide: This is the difference in the access and usage of technology between regions and areas that have the same identity. A proper explanation on the digital divide in Nigeria, chronicles the change in the accessibility, use of technological services between the rural and urban areas. Digital divide results from low literacy, infrastructural deficits and massive poverty.

Incessant Power Failure: This is one major problem affecting the successful implementation of e-governance in Nigeria. The power supply in the country is epileptic and unreliable. Power outage is a common occurrence in villages, towns and cities in Nigeria with negative influences on the robustness of the nation's ICT initiative. Most telecommunication stations are powered by constant generating sets and this affects the services rendered to the consumers, and the cost of running the base stations are transferred to consumers.

Low IT Professional Manpower: The level of ICT education in Nigeria is another problem facing the implementation of e-governance in Nigeria. During an interview with an official of the Nigerian Communication Commission (NCC), he gave detailed analysis on the deficiencies of staff performing e-services in many locations in Nigeria, and that the few skilled ones are overburdened (Nchuchuwe and Ojo, 2015).

\section{Concluding Remarks}

This study examined the relationship between of e-governance implementation and public 
service delivery in Nigeria, using the Technology Acceptance Model as a framework. The current situation of e-governance in the country is unsatisfactory for qualitative service delivery. Service quality has deteriorated and e-governance implementation should be seen as a means of improving service delivery. The obstacles identified and discussed above are threats to e-governance implementation in Nigeria. It is recommended that government should adopt the tenets of the Technology Acceptance Model (TAM), which would align the behaviour of users towards useful applications. There is also the urgent need for the governing elites to drive the ICT roadmap to strengthen administrative processes in the Nigerian public bureaucracy for impactful service in Nigeria. Finally, there should be adequate sensitization of public servants on the importance and benefits of adopting and implementing e-governance in the administrative and organizational processes that will ultimately lead to improved service delivery in Nigeria.

\section{References}

Abasilim, U. D., \& Edet, L. I. (2015). E-Governance and its Implementation Challenges in the Nigerian Public Service. Acta Universitatis Danubius. Administratio, 7(1), 30-42.

Abasilim, U. D., Gberevbie, D. E., \& Ifaloye, O. R. (2017). Attaining a better Public Service Delivery through E-Governance Adoption in Nigeria. In proceedings of the $4^{\text {th }}$ Covenant University Conference on e-Governance in Nigeria (CUCEN 2017), 109-118.

Abdulrazaq, K. A. (2015). Challenges of E-Government Implementation in the Nigerian Public Service. Journal of Creative Writing, 1(4), 45-56.

Ayo, C. K. (2014). Information and Communication Technology as a Lever for Innovation in Leadership. In T. Abioye, C. Awonuga, \& Amuwo, A. (eds) Leadership and Innovation in Africa's Development Paradigm. Ota: Covenant University Press, 71-90.

Azeez, N. A., Abidoye, A. P., Adesina, A. O., Agbele, K. K., Venter, I. M., \& Oyewole, A. S. (2012). Threats to E-Government Implementation in the Civil Service as a case study. The Pacific Journal of Science and Technology, 13(1), 398-402.

Banks, D. J., Oxman, S., R., \& Irish, P. (2002). Mission in Action: An Operational Definition of E-Government. National Defense University: Washington DC.

Bureau of Public Service Reforms. (2007). Nigeria Public Service Reform: In Country Senior Executive Seminar on Nigeria's Public Service Reform. State Banquet Hall, Abuja August, 20-22.

Ducey, A. J. (2013). Predicting Tablet Computer Use: An Extended Technology Acceptance. A thesis submitted in partial fulfillment of the requirements for the degree of Master of Arts Department of Psychology College of Arts and Sciences University of South Florida

Estevez, E., \& Janowski, T. (2013). Electronic Governance for Sustainable Development -Conceptual Framework and State of Research. Government Information Quarterly, 30(1), 94-109. https://doi.org/10.1016/j.giq.2012.11.001

Fatile, J. O. (2012) Electronic Governance: Myth or Opportunity for Nigerian Public 
Administration? International Journal of Academic Research in Business and Social Sciences, 2(9). 122-140.

Fox, W., \& Meyer, I., \&Van, H. (1996). Public Administration Dictionary. Kenwyn: Juta \& Co. Ltd.

Heeks, R. (1999), Reinventing Government in the INFORMATION Age: International Practice in IT-enabled Public Sector Reform. New York: Routledge. https://doi.org/10.4324/9780203204962

ITU. (2006). World ICT Development Report. ITU: Geneva, Switzerland.

Mohammed, S., Abubakar, M. K., \& Bashir, A. (2010). e-government in Nigeria: A Catalyst for National Development, in 4th International Conference on Development Studies, Nigeria. April, 2010.

Nchuchuwe, F. E., \& Ojo, A. D. (2015). Challenges and Prospects of Implementing e-Governance in Nigeria. Covenant University Journal of Politics and International Affairs (CUJPIA), 3(2).

Nkwe, N. (2012), E-Government: Challenges and Opportunities in Botswana. International Journal of Humanities and Social Science, 2(17), 39-48.

OECD. (Organisation for Economic Co-operation and Development). (2005). E-Government for Better Government. Paris: OECD.

Olatokun, W. M., \& Adebayo, B. M. (2012). Assessing E-Government Implementation in Ekiti State, Nigeria. Journal of Emerging Trends in Computing and Information Sciences. 3(4), 497-505.

Omeire, E., \& Omeire, C., (2014). New Wine in Old Wine Skin: An Exploration of Major Constraints to E-Government Implementation in Nigeria. European Scientific Journal, 10(14), 481-487.

Osawe, C. O. (2015). Reengineering Professionalism in the Public Service towards Service Delivery" Review of Public Administration and Management, 4(7), 63 -75.

Palvia, S. C. J., \& Sharma, S. S. (2007) E-government and E-governance: Definitions/framework and status around the world. Computer society of India. Conference on E-governance

Robinson, L. (2003). Committed to Quality: The Use of Quality Schemes in UK Public Leisure services, Managing Service Quality, 13(3), 247-55. https://doi.org/10.1108/09604520310476508

Shih, C. C., Shing, H. L., \& Chien, Y. L. (2011). Recent Related Research in Technology Acceptance Model: A Literature Review. Australian Journal of Business and Management Research, 1(9), 124-127.

Sunday, O. J. (2014). E-governance: An Imperative for Sustainable Grass root Development 


\section{Macrothink}

Journal of Public Administration and Governance ISSN 2161-7104 2017, Vol. 7, No. 4

in Nigeria. Journal of Public Administration and Policy Research, 6(4), 77-89. https://doi.org/10.5897/JPAPR2013.0264

Venkatesh, V., Morris, M. G., Davies, G. B., \& Davies, F. D. (2003). User Acceptance of Information Technology: Toward a Unified View. MIS Quarterly, 27(3), 425-478.

Wimmer, M., \& Traunmuller, R. (2001). Trends in Electronic Government: Managing Distributed Knowledge. In the Proceedings of the $11^{\text {th }}$ International Workshop on Database Expert Systems Applications, Springer, New York.

World Bank. (2004). World Development Report, New York, Oxford University Press.

Yayale, M. A. (2004). Public Service Transformation for Greater Service Delivery, in Management in Nigeria, Special Conference Edition, 4(2).

\section{Copyright Disclaimer}

Copyright for this article is retained by the author(s), with first publication rights granted to the journal.

This is an open-access article distributed under the terms and conditions of the Creative Commons Attribution license (http://creativecommons.org/licenses/by/4.0/). 